\title{
DRAG REDUCTION OF DENSE FINE-GRAINED SLURRIES
}

\author{
PAVEL VLASAK*), ZDENEK CHARA, PETR STERN \\ Institute of Hydrodynamics of Academy of Sciences of the Czech Republic, v. v. i., Pod Patankou 30/5, 16612 Prague 6, \\ Czech Republic; *) Corresponding author, Mailto: vlasak@ih.cas.cz, phone: +420 233109019, fax: +420 233324361
}

\begin{abstract}
Attractive and repulsive forces acting in the slurry due to different ions absorbed on surface of fine particles, especially colloidal ones, strongly affect the flow behaviour of highly concentrated fine-grained slurries. The attractive forces between the fine-grained solid particles initiate the coagulation process, which gives rise to voluminous aggregates where a large amount of water is fixed. A modification of the physicalchemical environment of the slurry by addition of a peptizing agent produces repulsive forces between particles. They result in destruction of the aggregates, water originally fixed in the aggregates is liberated, the viscous friction can play a larger role in the slurry, which is liquefied. To prove these process three different kaolin-water mixtures were tested with an overpressure capillary viscometer, rotational viscometer, and experimental pipeline loop. The effect of two peptizing agents and their concentration was investigated. It was demonstrated that even very low concentration of peptizing agent results in a significant reduction in the apparent viscosity and in the yield stress.
\end{abstract}

KEY WORDS: Kaolin Slurry, Drag Reduction, Experimental Investigation, Peptization, Slurry Rheology.

Pavel Vlasák, Zdeněk Chára, Petr Štern: SNIŽOVÁNÍ TŘENÍ ZAHUŠŤĚNÝCH JEMNOZRNNÝCH SUSPENZÍ. J. Hydrol. Hydromech., 58, 2010, 4; 13 lit., 10 obr., 2 tab.

Přitažlivé a odpudivé síly působící mezi částicemi v suspenzi v důsledku různých iontů absorbovaných povrchem jemných, zejména koloidních částic, silně ovlivňují tokové chování vysoce koncentrovaných jemnozrnných suspenzí. Přitažlivé síly mezi jemnými částicemi iniciují proces koagulace, umožňují vznik objemných agregátů, v nichž je vázáno značné množství vody. Změna fyzikálně-chemického prostředí suspenze přidáním peptizačního činidla podpoří vznik odpudivých sil mezi částicemi, které způsobí rozbití objemných agregátů a voda vázaná $\mathrm{v}$ agregátech se uvolní, vazké tření tak bude hrát v suspenzi významnější roli a dojde $\mathrm{k}$ ztekucení suspenze. Tento proces byl ověren experimentálním výzkumem třech různých kaolinových suspenzí jednak na kapilárním přetlakovém viskozimetru, na rotačním viskozimetru a na experimentální potrubní trase. Byl ověřen účinek dvou peptizačních činidel a bylo ukázáno, že velmi nízká koncentrace peptizačního činidla vede $\mathrm{k}$ významné redukci zdánlivé viskozity a počátečního napětí.

KLÍČOVÁ SLOVA: kaolinové suspenze, snižování tření, experimentální výzkum, peptizace, reologie suspenzí.

\section{Introduction}

Many mining, building and other industrial materials are handled, transported and processed in the form of fine-grained highly concentrated watersolid mixtures, so called dense slurries or pastes. Technological processes, transport and storage, treatment or final deposition of such slurries require advanced knowledge of their rheological behaviour for design and safe, reliable and economical operation.

The presence of fine-grained solid particles in a Newtonian liquid evokes complex rheological behaviour of the slurry due to the mutual interactions of both the liquid and the solid phases. During the slurry flow hydrodynamic interactions are caused by shear-induced translational and rotational motions of the particles, resulting in particle collisions and the formation of temporary multiplexes. Such interactions lead to an increase in the rate of viscous energy dissipation and hence the bulk viscosity of the slurry. Non-hydrodynamic interactions, which are most significant in colloidal systems, originate from random Brownian motion of particles and colloidal forces due to the van der Waals attractive forces and electrostatic repulsive forces. Interparticle interactions of non-hydrodynamic 
origin usually evoke non-Newtonian behaviour of the slurry.

In highly concentrated fine-grained suspensions both types of interactions exist, and their relative influence on the rheology is a function of the physical and electrochemical characteristics of the particles, the nature of the suspending liquid, and the type and intensity of the flow (Nguyen and Boger, 1984).

If the attractive forces acting in the slurry prevail, a process of coagulation and sedimentation is initiated. However, simultaneous existence of the repulsive forces enables the slurry to be stabilized and keeps individual particles separated. The effect of the electrostatic repulsive forces on the stabilization process could quite well explain a mechanism of liquefaction of clay slurries based on the reduction in the apparent viscosity and the yield stress by addition of an inappreciable quantity of chemical agent resulting in a change in the physical-chemical behaviour of suspended particles (Šatava, 1973).

The flow behaviour of dense slurries not only depends on the physical parameters of the slurry components (particle size distribution, shape, density and concentration, liquid density and viscosity) but is also strongly affected by the mutual particleparticle and particle-liquid interaction and by physical-chemical forces acting in the slurry.

The solid particles of real industrial materials (minerals, metal ores, ceramic raw materials, ash, tailings, and other wastes) are not of spherical shape and uniform size, and the slurry flow behaviour can be strongly affected by physical-chemical forces acting in the slurry. The description of flow behaviour of dense slurries can be based on the presence of attractive and repulsive forces acting simultaneously in the slurry (Verwey and Overbeck, 1948).

Understanding the inner structure and complex slurry behaviour makes possible to optimize energy and water requirements and to improve the quality and economy of transport and/or processing.

\section{Physical-chemical behaviour of kaolin slurry}

Kaolin is a relatively uniform material and its water suspension is very often used as the model slurry for investigation of the yield pseudo-plastic liquids. Let us look in more detail the kaolin particle, which is actually a table shaped crystal of kaolinite. The kaolinite crystal can be imagined as a "pack of cards", where each card consists of two units - the first layer is built from tetrahedrons of silicon dioxide, $\mathrm{SiO}_{4}$, and the second layer from hexahedrons of aluminium hydroxide $\mathrm{Al}(\mathrm{OH})_{6}$, mutually connected by covalent bonds.

A sketch of this aggregate - the double-layer constituent - is given in Fig. 1. The set of doublelayers is situated so that they are placed one by one in parallel position with higher or lower regularity according to the quality of the kaolinite crystal. In the crystal grid of kaolinite some imperfections due to the isomorphic substitution of quartz by aluminium or by iron can be found. Due to the substitution the kaolin surface layer becomes not electro-neutral and an unsaturated negative charge which plays an important role in the slurry behaviour exists.

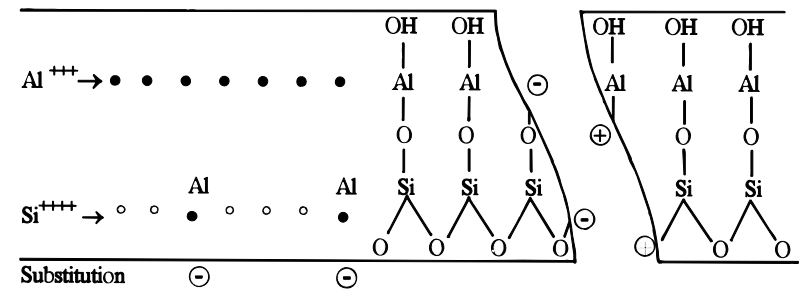

Fig.1. Sketch of quartz substitution and breaking of kaolinite crystal.

Obr. 1. Schéma substituce křemíku a mechanicky poškozeného krystalu kaolinitu.

Further on the kaolinite crystals could be imperfect also from the macroscopic point of view, they could be broken or their edges could be knocked off. As a consequence of these defects the bonds between atoms of quartz and oxide (Si-O) or aluminium and oxide (Al-O) in the crystal grid are also broken, and because water is always slightly dissociated on $\mathrm{H}^{+}$and $\mathrm{OH}^{-}$ions, the impaired surface of the kaolinite adsorbs $\mathrm{OH}^{-}$anions from dissociated water. Si-OH and $\mathrm{Al}-\mathrm{OH}$ groups are formed in contact with defective kaolinite surface. The behaviour of both groups differs depending on the slurry acidity. For slurry with a low $\mathrm{pH}$, the $\mathrm{Si}-\mathrm{OH}$ groups remain stable; at a higher $\mathrm{pH}$ they dissociate $\mathrm{H}^{+}$ cations and a negative charge remains on the solid surface. In contrast, Al-OH groups dissociate $\mathrm{OH}^{-}$ anions in slurry of a low $\mathrm{pH}$ value and thus the solid surface charge is positive; at a high $\mathrm{pH} \mathrm{H}^{+}$ cations are dissociated and the surface charge is negative in a similar way as for $\mathrm{Si}-\mathrm{OH}$ groups. The existence of negative charges on kaolinite edges at low $\mathrm{pH}$ values was proved by Schoffield and Samson (1954), who stated that when the kaolin-water mixture has a low $\mathrm{pH}$, the kaolinite adsorbs anions 
from dissociated carrier liquid, while at a high $\mathrm{pH}$ this effect was not found.

A number of negative charges on the surface of the kaolin particle are originated due to the substitution in the crystal grid and electrolytic dissociation of $\mathrm{Si}-\mathrm{OH}$ or $\mathrm{Al}-\mathrm{OH}$ groups. Around the charged particle a layer consisting of cations dissociated in the carrier liquid is formed, which together with charged surface create an electrical doublelayer.

The thickness of the double-layer depends on the value of surface charge and the kind and concentration of dissociated cations, which have to balance the surface charge. The greater the charge and concentration of the cations and the smaller their size, the thinner the surrounding layer that could serve to compensate the charge of the particle surface. Hence, the large hydrated monovalent cations such as $\mathrm{Na}^{+}, \mathrm{Ka}^{+}, \mathrm{Li}^{+}$, and $\mathrm{NH}_{4}^{+}$, with a small specific ion charge, produce a thick ion "atmosphere" around the particle. The medium thickness of the double-layer is evoked by bivalent ions of calcium $\mathrm{C}^{++}$or magnesium $\mathrm{Mg}^{++}$and the thinnest doublelayer arises if the surface charge is compensated by trivalent aluminium ions $\mathrm{Al}^{+++}$.

The particles in the suspension tend to bunch into bigger aggregates since it decreases the total energy of the system. The thinner the electrical doublelayer, the closer the individual particles can come to each other, penetrate to the field of activity of at- tractive molecular forces, and contact each other, what is a necessary condition for the coagulation process in the slurry to start.

Depending on the acidity of the slurry, we can distinguish two patterns of coagulation. On the flat surface of the kaolinite crystal only negative charges can exist due to the quartz substitution, but on the edges and fractures the charge depends on the $\mathrm{pH}$ of the slurry and is given by the process of dissociation.

For $\mathrm{pH}>7$ the Si-OH and Al-OH groups liberate hydrogen cation $\mathrm{H}^{+}$and the negative charges remain on the edges of the kaolinite crystal. Thus only the negative charges exist on the surface of solid particles and the table shaped crystals of kaolinite attach together flat by flat and create the so called "pack of cards" (see Fig. 2) during the process of coagulation. In contrast, for $\mathrm{pH}<7$ the $\mathrm{OH}^{-}$ anions are dissociated from the Si-OH and $\mathrm{Al}-\mathrm{OH}$ groups on the edges of crystals, so that negative charges are on the plain of crystals while positive charges exist on the edges. Due to Brownian motion the solid particles turn up so that negative and positive charges mutually compensate each other, and the resulting inner structure of the slurry can be described as irregularly "honey combed" or as a "house of cards" pattern.

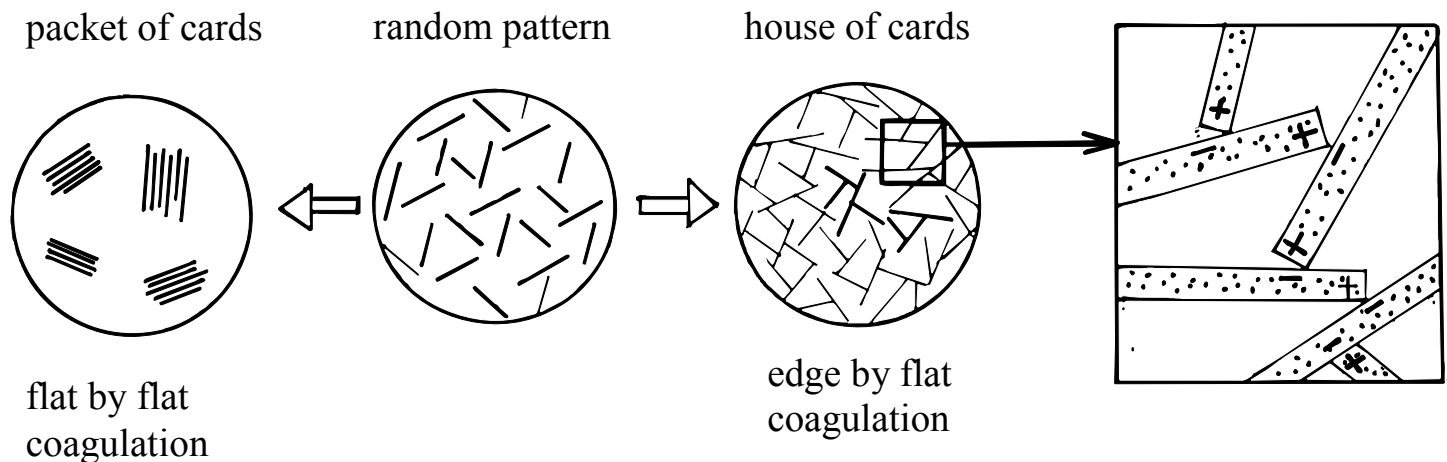

Fig. 2. Mechanism of coagulation of kaolin slurry.

Obr. 2. Mechanismus koagulace kaolinové suspense.

For higher concentration of solids, this structure could fill up the whole volume of the slurry. This means that for slurry of low $\mathrm{pH}$ the coagulation process in the kaolin-water mixture gives to rise to voluminous aggregates with a loose structure where a large amount of water is fixed. Therefore, during the slurry flow a viscous friction in the carrier liquid can act only on a small-scale, and more energy is consumed in the aggregate deformation. Nevertheless, if due to a change in the slurry environment (change in the $\mathrm{pH}$ and/or content of dissociated cations) the inner structure of the slurry and the 
voluminous aggregates are broken up into individual particles or smaller packets of particles, water originally fixed in aggregates is liberated, and the slurry becomes peptised. Only a small part of the water remains bonded in a thin layer around the particles. During the slurry flow, viscous friction can be exerted on a much greater scale - the apparent viscosity is decreasing and the slurry is liquefying (Vlasak et al.,1999b).

\section{Experimental equipment and procedure}

To prove the possibility of liquefying kaolin slurries, three kinds of the kaolin were tested. The individual kinds of kaolin differ according to the particle size distribution (see Tab. 1) and chemical composition (see Tab. 2). Horsley and Snow (1988) have shown that for determination of the yield stress and apparent viscosity of slurry, the chemical composition is equally as important as the solid concentration and particle size distribution.

$\mathrm{T}$ a b $1 \mathrm{e}$ 1. Particle size distribution of the kaolin used.

T a b u $1 \mathrm{k} \mathrm{a} 1$. Zrnitostní rozdělení použitých kaolinů.

\begin{tabular}{lccccccccccc}
\hline Kaolin & $\begin{array}{c}d_{50} \\
{[\mu \mathrm{m}]}\end{array}$ & $\begin{array}{c}\rho \\
{\left[\mathrm{kg} \mathrm{m}^{-3}\right]}\end{array}$ & $\begin{array}{c}d \\
{[\mu \mathrm{m}]}\end{array}$ & $<1$ & $1-2$ & $2-4$ & $4-6$ & $6-10$ & $10-20$ & $20-30$ & $d_{\max }$ \\
\hline Sedlec-S1a & 1.5 & 2507 & mass & 41 & 18 & 19 & 10 & 9 & 3 & - & 15 \\
Sedlec-MK & 6 & 2505 & content & 21 & 7 & 9 & 9 & 17 & 32 & 5 & 30 \\
H. Bríza-HB & 3 & 2549 & {$[\%]$} & 28 & 12 & 22 & 21 & 11 & 6 & - & 20 \\
\hline
\end{tabular}

$\mathrm{T}$ a b 1 e 2. Chemical composition of the kaolin used.

$\mathrm{T} \mathrm{a} \mathrm{b} \mathrm{u} 1 \mathrm{k}$ a 2 . Chemické složení použitých kaolinů.

\begin{tabular}{cccccccccc}
\hline Kaolin & $\mathrm{SiO}_{2}$ & $\mathrm{Al}_{2} \mathrm{O}_{3}$ & $\mathrm{Fe}_{2} \mathrm{O}_{3}$ & $\mathrm{CaO}$ & $\mathrm{MgO}$ & $\mathrm{K}_{2} \mathrm{O}$ & $\mathrm{Na}_{2} \mathrm{O}$ & $\mathrm{TiO}_{2}$ & Residue \\
\hline Sedlec -S1a & 47.84 & 35.83 & 0.92 & 0.50 & 0.37 & 1.11 & 0.06 & 0.24 & 13.13 \\
Sedlec-MK & 50.56 & 34.56 & 1.08 & 0.21 & 0.29 & 1.61 & 0.07 & 0.39 & 11.23 \\
H. Bríza-HB & 50.33 & 35.06 & 0.67 & 0.07 & 0.20 & 1.38 & 0.09 & 0.93 & 11.27 \\
\hline
\end{tabular}

They also found out that high content of magnesium and calcium compounds in the slurry obstructs modification of the slurry behaviour. All the investigated kinds of kaolin have similar content of the basic components (quartz, aluminium, and iron oxides mass content is about $85 \%$ ) but the difference in the calcium and magnesium oxide is rather significant. The kaolin slurry was investigated for three mass concentrations $c_{m}=0.39,0.50$ and 0.55 .

The average particles diameters of the used kaolin differ significantly, as do the contents of colloidal particles (see Tab. 1). The highest content of particles of less than $1 \mu \mathrm{m}$ was found for kaolin S1a, as was nearly twice as high as those of the other two kaolins. The higher content of colloidal particles and also of magnesium and calcium compounds could be the reason for the higher yield stress values reached for this kind of kaolin.

Sodium carbonate and soda water-glass were used as a peptizing agent in the mass concentration varying from $c_{a}=0.02$ to $2 \%$. Both additives can supply the slurry with $\mathrm{Na}^{+}$cations for the compensation of the surface charge. The calcium ions in the slurry are precipitated in the form of insoluble calcium carbonate or low solubility calcium silicate, respectively.
The sodium carbonate $\mathrm{Na}_{2} \mathrm{CO}_{3}$ represents a peptizing agent which supplies the slurry with stabilizing $\mathrm{Na}^{+}$cations and simultaneously bonds the original adsorbed bivalent cations in the form of insoluble calcium or magnesium carbonate. The soda-water-glass $\mathrm{Na}_{2} \mathrm{SiO}_{3}$ represents a peptizing agent with colloidal anions. The anion of waterglass is in reality a macromolecule with a basic building unit $\mathrm{SiO}_{4}$. During liquefying of the slurry it supplies the slurry with $\mathrm{Na}^{+}$cations and one part of the liberated anions, the smaller one being bound in low solubility calcium silicate, $\mathrm{CaSiO}_{3}$. The greater portion of liberated anions is absorbed on kaolin particles, where it helps to create a thin layer of carrier liquid which prevents coagulation of individual particles. Thus the effect of water-glass can be even more favourable than that of sodium carbonate or sodium hydroxide.

The kaolin slurry samples were prepared according to uniform prescriptions to avoid random influences on rheological properties of measured slurries. The dry kaolin was weighed out in a glass bottle, an exact quantity of distilled water as well as the determined quantum of peptizing agent was added, and the mixture was thoroughly stirred. Then each glass bottle was hermetically sealed for 
two days to reach perfectly homogeneous slurry and to avoid a time effect (Vycudilik, 1974).

Rotational and capillary rheometers and also experimental pipeline loop were used to determine the flow behaviour of kaolin slurry without and with peptizing agent. To evaluate the influence of shearing pattern and slip effect, a vertical control overpressure capillary viscometer (VOCV), developed in the Institute of Hydrodynamics of ASCR in Prague, was used (Vlasak et al., 1999a). Six different capillaries (I.D. 2.04, 2.52, 2.82, 3.51, 5.21 and $5.92 \mathrm{~mm}$ ) were used according to the concentration of kaolin and peptising agent. With the capillary viscometer velocity gradient up to $10^{4} \mathrm{~s}^{-1}$ was reached. The VOCV was calibrated with glycerine to evaluate the influence of the end effects. The slip effect was found to be relatively small; the influence of capillary diameter is not significant (see Fig. 3).

A Haake Rotavisco RV 20 rotational viscometer was used for the velocity gradient range from 0 to $200 \mathrm{~s}^{-1}$ and for a limited number of samples, up to $1200 \mathrm{~s}^{-1}$. Results obtained from capillary and rotational viscometers were found to be in good agreement (see Fig. 3, where the dependence of shear stress on velocity gradient is illustrated). For selected slurries yield stress was also measured using a simple geometry and vane rotor adapted to the Haake Rheometer RT 10. This technique, originally developed in soil mechanics, allows the yield stress to be determined with a reasonable accuracy directly from a single-point determination (Keentok, 1982). The rotational viscometer was used for a velocity gradient range from 0 to $200 \mathrm{~s}^{-1}$ and for a limited number of samples, up to $1200 \mathrm{~s}^{-1}$.

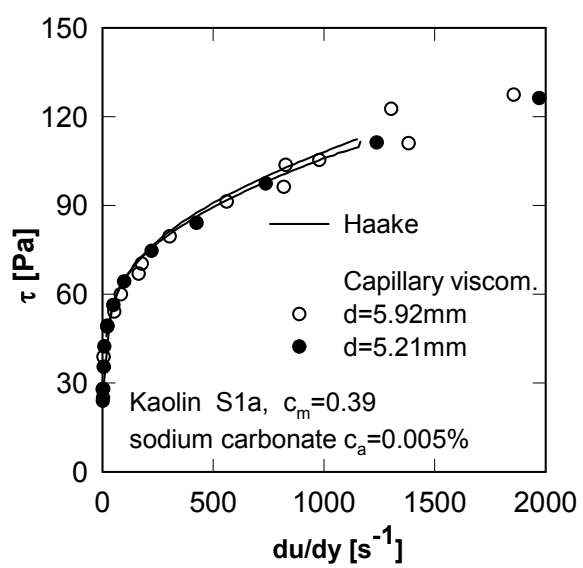

Fig. 3. Dependence of shear stress on velocity gradient. Comparison of capillary and rotational viscometers data.

Obr. 3. Závislost smykového napětí na rychlostním gradientu. Srovnání výsledků kapilárního a rotačního viskozimetru.
Also, an experimental re-circulation pipeline loop with a test section from a hydraulically smooth stainless steel pipe of inner diameter $D=17.5 \mathrm{~mm}$ was used to prove the flow behaviour and the process of peptization during the flow of kaolin-water slurry in a pipe (Vlasak et al., 2002). Kaolin slurry was forced by a screw pump with phase advancer from an agitated storage tank. The installation makes it possible to operate in laminar and turbulent regimes up to an average slurry velocity of $V_{a v}$ $\approx 8 \mathrm{~m} \mathrm{~s}^{-1}$. Pressure losses were measured by Hottinger-Baldvin PD-1 differential pressure transducers monitored by computer. At the pipe outlet a box divider was mounted which allowed measurement of the mass flow rate and volume concentration (Vlasak and Chara, 1999). The temperature of the slurry was kept in the range $t \approx 18{ }^{\circ} \mathrm{C}$ with the help of a heat exchanger situated at the beginning of the transport pipe.

Based on the experience from the measurements realized with rotational and capillary viscometers, the kaolin from the Horni Briza workstation and sodium carbonate as a peptizing agent were used for the loop measurement. Kaolin slurries with volumetric concentrations varying from $c_{v}=3$ to $36 \%$ were tested for laminar, laminar/turbulent transition, and turbulent regimes. The peptizing agent $/$ kaolin mass ratio was varied from $c_{a}=0.05$ to $0.30 \%$, which corresponds with optimum efficiency (Vlasak et al., 1999b). A Haake RheoStress 300 rheometer was used to determine the flow behaviour of kaolin slurry with and without peptizing agent after measurement in the pipe loop.

\section{Results and discussion}

The highly concentrated water-kaolin mixtures can be characterized as yield-pseudoplastic slurries. The effect of peptizing agents, the sodium carbonate and soda water-glass, and their concentrations for different slurry concentrations and kind of kaolin was investigated. A significant decrease in the apparent viscosity and the yield stress was observed due to the addition of the peptizing agents. The difference in shear stress between coagulated and peptized slurries can achieve values of an order of magnitude depending on the solids and peptizing agent concentrations.

A mutual effect of the attractive and the repulsive forces between the solid particles determines the flow behaviour of the system. The magnitude of the inter-particle forces depends on physical and chemical properties of the both phases. By addition 
of the appropriate cations into the slurry the repulsive forces between particles prevail and the viscosity and the yield stress decrease. The effect depends on the peptizing agent concentration (see Fig. 4). With increasing concentration of the agent, the apparent viscosity and the yield stress first decreases quickly, and then after exceeding of the optimal value of the agent concentration both

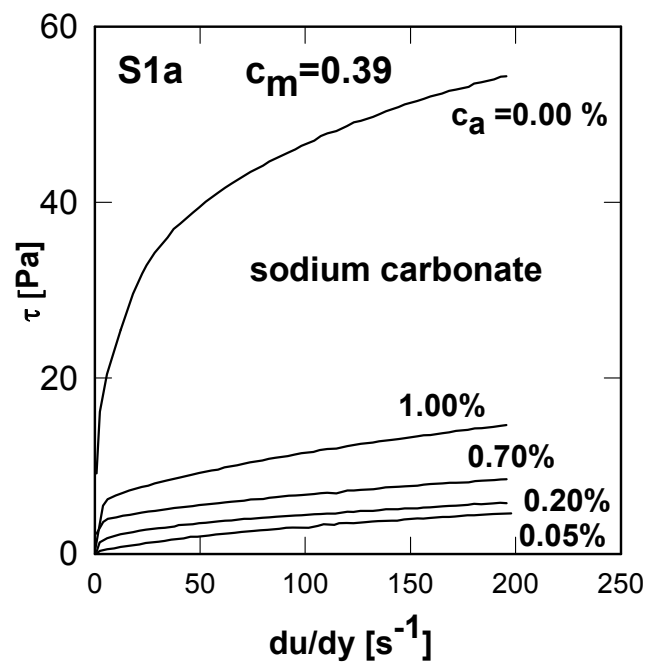

Fig. 4. Effect of peptizing agent concentration on shear stress.

Obr. 4. Vliv koncentrace peptizačního činidla na smykové napětí.

The effects of the kind and concentration of the peptizing agent are illustrated in Fig. 5. For agent concentration $c_{a}$ higher than about $0.15 \%$ the efficiency of water-glass is significantly higher than that of sodium carbonate. Even very low concentration of peptizing agent results in rather remarkable decrease of both yield stress and apparent viscosity. If the sodium carbonate concentration exceeds the optimal value, its efficiency decreases and the process of slurry re-coagulation can be observed, as well as the increase of $\mathrm{pH}$ from the original value of about $\mathrm{pH}=6$ up to $\mathrm{pH} \sim 10.5$ for $\mathrm{c}_{\mathrm{a}}=1.0 \%$. In contrast to sodium carbonate, no process of recoagulation was observed for water-glass after its concentration overstepped the maximum efficiency value.

A similar effect of agent concentration was observed for the different slurry concentration (see Fig. 6): the tendency of re-coagulation seems to be nearly independent of the concentration of solids, but it was observed to be higher for the lower velocity gradient value.

The effect of the sodium carbonate concentration was observed to be very similar for different rheological quantities again increase and the recoagulation process resumes. The optimal flow regime (with a minimum shear stress) is reached for a peptizing agent concentration varying from $c_{a}=$ $=0.05$ to $0.20 \%$, depending on the kind of kaolin and slurry concentration (Vlasak et al., 1999b).

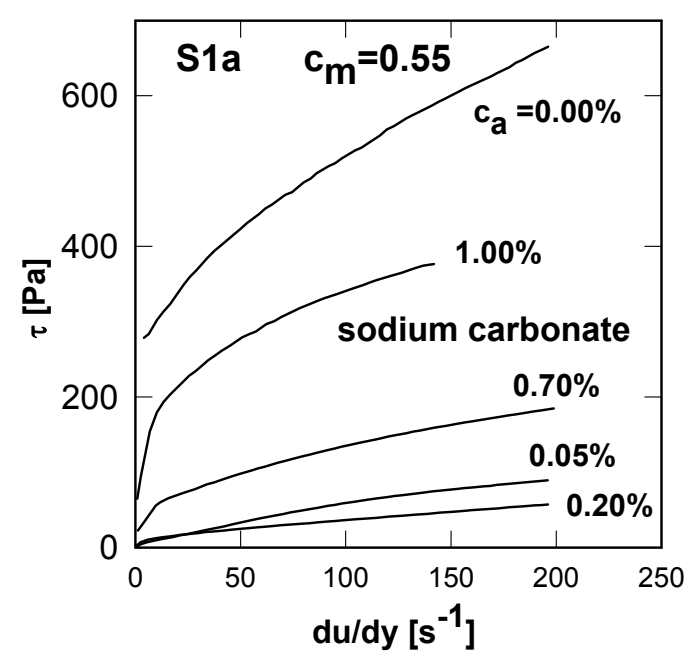

slurry concentrations, and the tendency to recoagulation seems to be nearly independent on the kind of kaolin and slurry concentration. From the point of view of the type of kaolin, the best results were observed for Sedlec MK kaolin. The peptization effect for the other two types is similar, but considerably lowers (see Fig. 7).

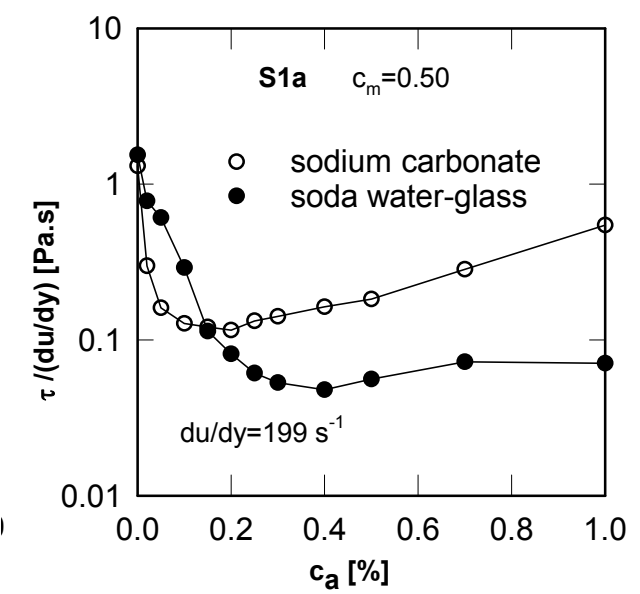

Fig. 5. Effect of kind and concentration of the peptizing agent. Obr. 5. Vliv druhu a koncentrace peptizačního činidla. 

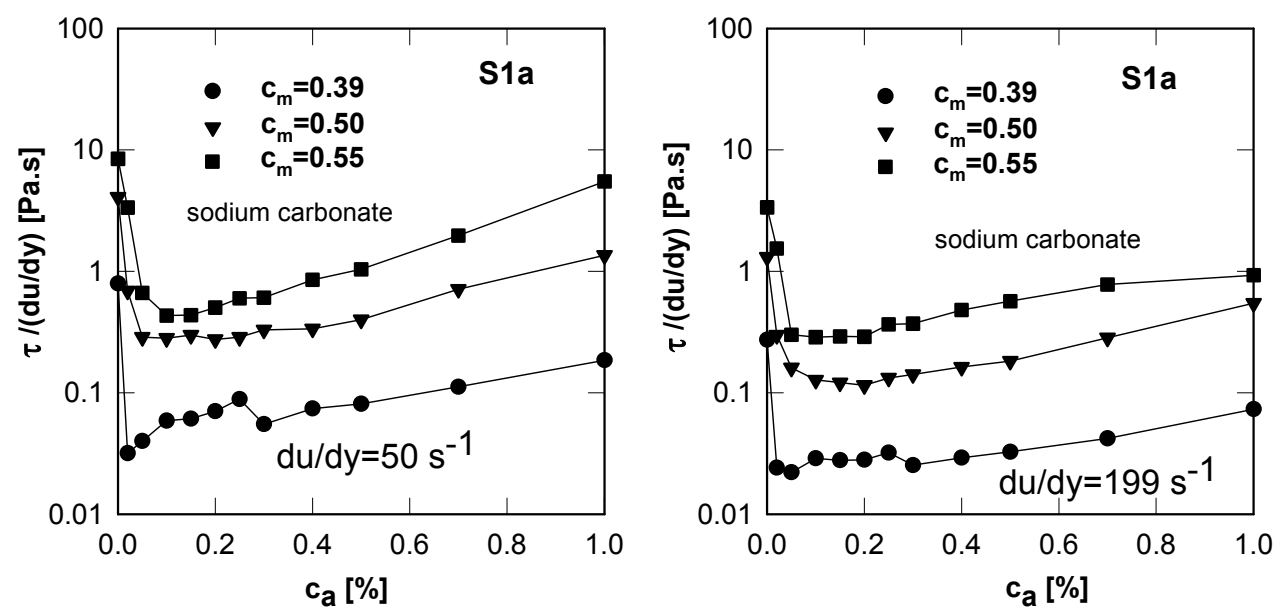

Fig. 6. Effect of peptizing agent concentration and solids concentration. Obr. 6. Vliv koncentrace peptizačního činidla a koncentrace pevné fáze.
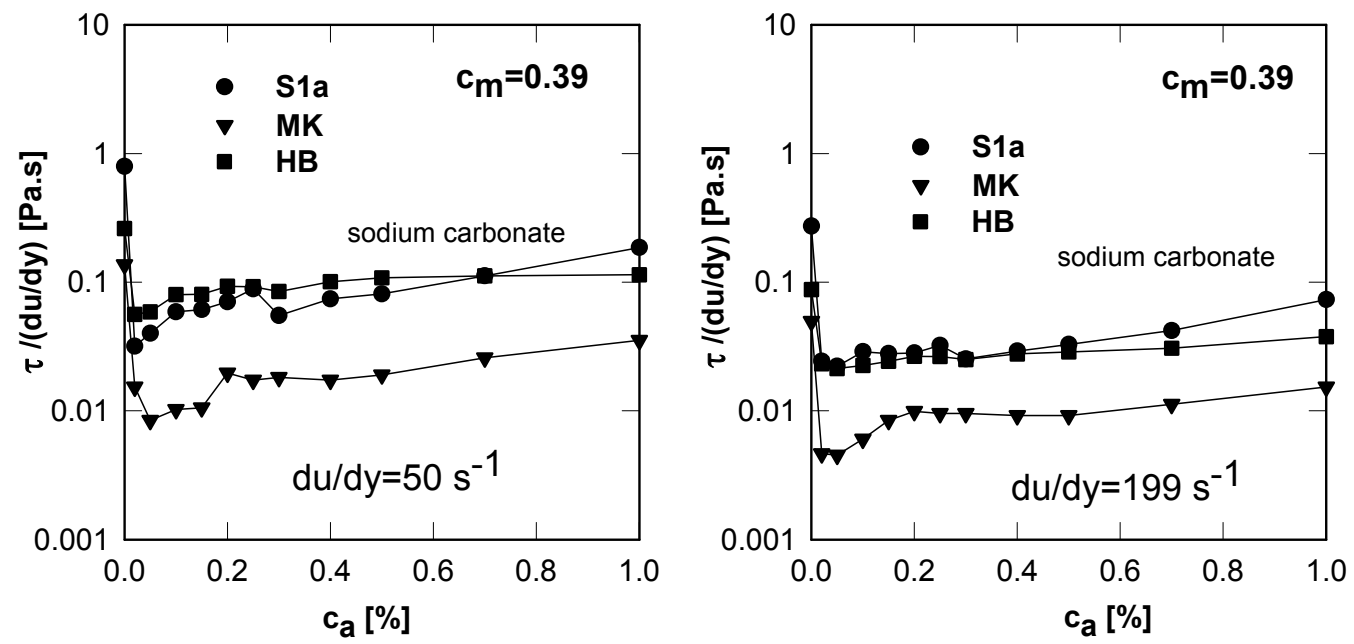

Fig. 7. Effect of peptizing agent concentration and kind of suspended material.

Obr. 7. Vliv koncentrace peptizačního činidla a druhu pevné faze.

A great deal of dilution of the kaolin slurry treated by peptizing agent is produced due to the substantial decrease in the yield stress. The addition of sodium carbonate with a mass concentration of about $0.1 \%$ produces an increase in the $\mathrm{pH}$ of the slurry from the original $\mathrm{pH} \sim 6$ to $\mathrm{pH} \sim 7$. The surface charges of particles become compensated by adsorbed $\mathrm{Na}^{+}$cations, and calcium ions are precipitated as insoluble carbonates. The adsorbed $\mathrm{Na}^{+}$ ions form a thick ionic atmosphere around particles, which prevents the approach of particles into the range within which attractive forces work. The slurry becomes stabilized, the yield stress nearly disappears, and the flow behaviour of the slurry tends to the Newtonian model.
The influence of the sodium carbonate concentration on the yield stress is shown in Fig. 8. For the kaolin MK and S1a the original value of the yield stress of the kaolin slurry with concentration $c_{m}=$ $=0.55$ could be reduced from $\tau_{y}=134 \mathrm{~Pa}$ to $6 \mathrm{~Pa}$ for $c_{a}=0.15 \%$ and from $\tau_{y}=34.1 \mathrm{~Pa}$ to $0.5 \mathrm{~Pa}$ for $c_{a}=0.1 \%$, respectively. Such a dramatic reduction in the yield stress, in the range of 20 or even nearly 100 fold, has substantial importance in liquefying dense kaolin slurry. It follows from Fig. 8 that for a relatively high concentration of a peptizing agent, $c_{a} \sim 2.0 \%$, the yield stress reaches the original value of the untreated slurry and the effect of the agent vanishes. 


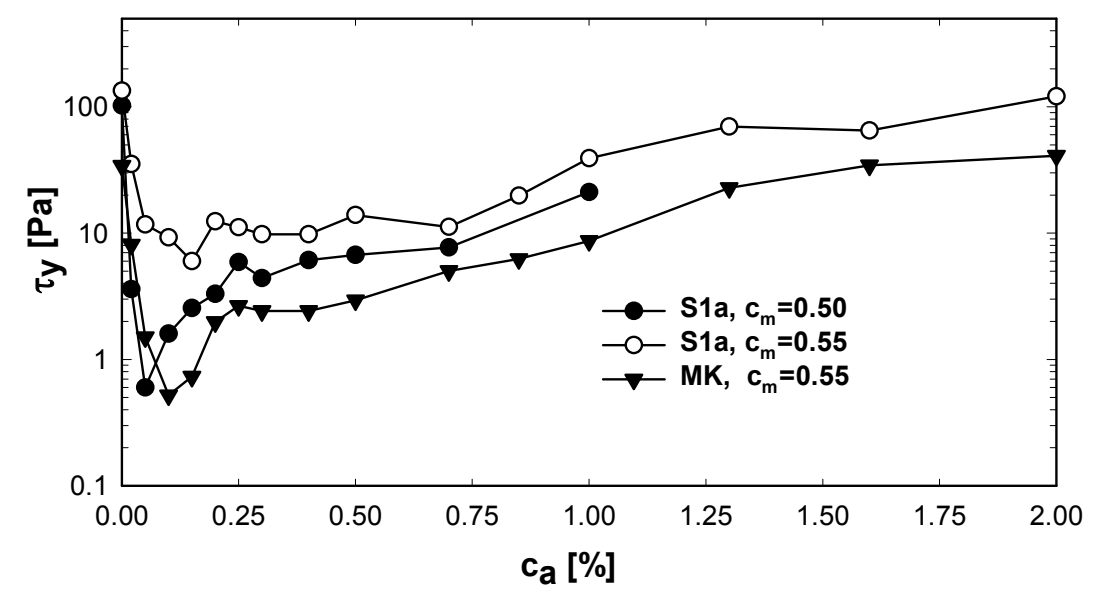

Fig. 8. Effect of type of kaolin and concentration of soda carbonate $c_{a}$ on the yield stress $\tau_{y}$. Obr. 8. Vliv druhu kaolínu a koncentrace uhličitanu sodného $c_{a}$ na počáteční napětí $\tau_{y}$.

The pipe loop investigation confirmed the results obtained by rheometrical measurement of concentrated kaolin slurry (Vlasak et al. 1999a, 1999b). The untreated and peptised slurries of $c_{v}=10,23$, 27 , and $36 \%$ were measured in an experimental pipeline loop to prove the effect of peptization on kaolin slurry during pipe flow under laminar and turbulent conditions (Vlasak and Chara, 1999, 2004, 2009). The flow behaviours of peptized and untreated kaolin slurry in a pipe are considerably different (see Fig. 9 and 10).

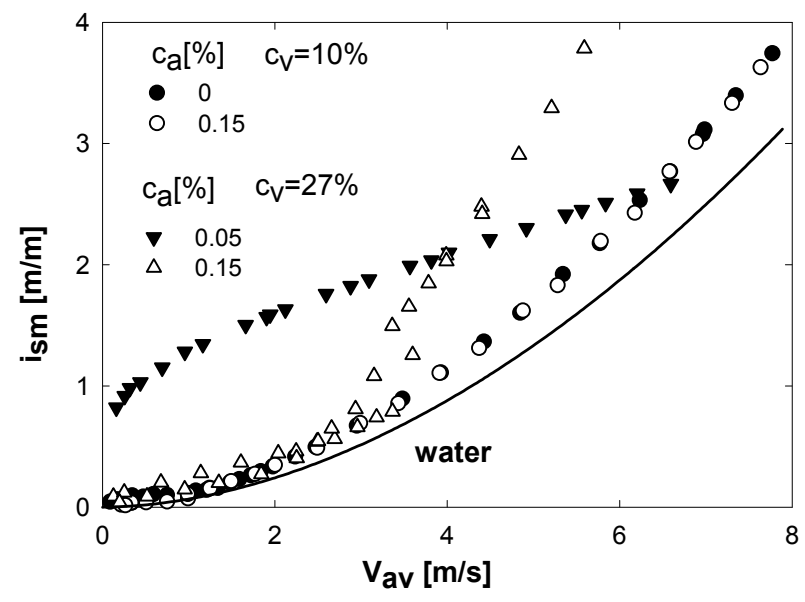

Fig. 9. Effect of peptizing agent concentration $c_{a}$ on hydraulic gradient $i_{s m}$ (Sedlec-S1a kaolin slurry of $c_{v}=10$ and $27 \%$ ).

Obr. 9. Vliv koncentrace peptizačního činidla $c_{a}$ na sklon tlakové čáry $i_{m}$ (Sedlec-S1a kaolinová suspense, koncentrace $c_{v}$ $=10$ a $27 \%$ ).

For a low slurry concentration the peptizing agent acted in the laminar region only. The yield stress practically vanishes and the hydraulic gradi- ent/velocity relationship is very close to the values for water alone. Practically no difference between peptized and untreated slurry in the transient and turbulent regimes can be found for the higher velocity region. The effect of peptization becomes essential for slurry concentration higher than $c_{v} \sim$ $25 \%$. In the laminar regime a substantial decrease in the hydraulic gradient of about $30 \%$ was observed. In the turbulent region the positive effect depends on slurry flow velocity $V_{a v}$ and on the peptizing agent/kaolin mass ratio $c_{a}$. We can see also a decrease in the velocity value corresponding to the transient point from about $V_{t r} \sim 7.8 \mathrm{~m} \mathrm{~s}^{-1}$ to $V_{t r} \sim 6.3$ $\mathrm{m} \mathrm{s}^{-1}$ for a slurry concentration of $c_{v}=23 \%$ and a peptising agent $/$ kaolin mass ratio $c_{a}=0.05 \%$. Behind the transient point, the hydraulic gradient $i_{s m}$ of peptized slurry quickly increases and at $V_{a v} \sim 6.7$ $\mathrm{m} \mathrm{s}^{-1}$ exceeds the value of untreated slurry.

For peptizing agent/kaolin mass ratio of $c_{a}=$ $=0.10 \%$ the peptized slurry shows only slightly non-Newtonian behaviour. The laminar/turbulent transient point is around slurry velocity $V_{t r} \sim 3.0$ $\mathrm{m} \mathrm{s}^{-1}$. In the transient region the hydraulic gradient increases steeply and in the turbulent region the peptized slurry behaves practically as a Newtonian liquid with a viscosity and a density higher than those of water. For $c_{a}=0.15 \%$ the peptized slurry seems to be a Newtonian liquid even in the laminar regime. The transient region is reached at a relatively low slurry velocity of $V_{t r} \sim 2.0 \mathrm{~m} \mathrm{~s}^{-1}$. However, at a slurry velocity of about $V_{a v} \sim 5.0 \mathrm{~m} \mathrm{~s}^{-1}$ hydraulic gradient of peptized slurry exceeds the values valid for untreated slurry and from the benefit of peptization vanishes. 


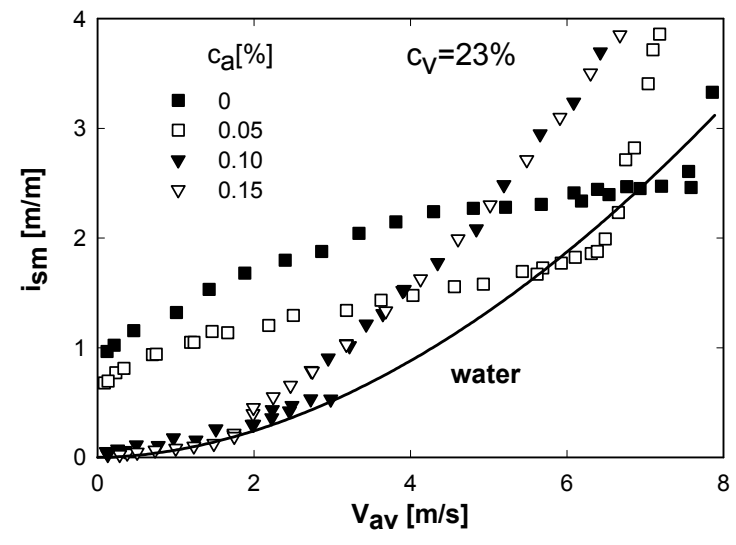

Fig. 10. Effect of peptizing agent concentration $c_{a}$ on hydraulic gradient $i_{s m}$ (Sedlec-S1a kaolin slurry of $c_{v}=23 \%$ ).

Obr. 10. Vliv koncentrace peptizačního činidla $c_{a}$ na sklon tlakové čáry $i_{m}$ (Sedlec-S1a kaolinová suspense, koncentrace $c_{v}$ $=23 \%$ ).

\section{Conclusions}

The present investigation confirms the possibility of substantial reduction in the yield stress and the apparent viscosity of highly concentrated finegrained slurries containing colloidal particles due to a modification of their physical-chemical behaviour. The addition of peptizing agent enables a much higher operational solids concentration and/or very profitable energy consumption to be reached for the hydraulic transport, handling and processing of industrial slurries.

The behaviour of the kaolin slurry is controlled by a mutual effect of the attractive and repulsive forces between the solid particles given by the physical and chemical properties of both phases.

The peptizing agent (sodium carbonate) supplies the slurry with monovalent cations for the compensation of the surface charge of particles, significantly affects the flow behaviour of kaolin slurries, and helps much higher concentrations of solids and/or lower energy consumption to be achieved during the flow of slurry in a pipe. With increasing concentration of the peptizing agent the apparent viscosity and yield stress gradually decrease, and the later even vanishes. For highly peptizing agent contents, the transition from non-Newtonian to Newtonian behaviour was observed. The efficiency of the slurry liquefying process depends on the peptizing agent and the solids concentration and flow velocity of the slurry. The effect of the peptizing agent increases with kaolin concentration and is significant for the laminar regime. The laminar/turbulent transition point is reached for peptized slurries at a significantly lower flow velocity compared to untreated slurry. For the transition and especially for turbulent regime the positive energy consumption effect has to be evaluated for each event.

The control of the physical-chemical behaviour and inner structure of the slurry makes it possible to optimize both the energy and water consumption and to improve the quality and economy of the transport, handling, and processing of the slurry.

Acknowledgements. The authors gratefully acknowledge the support of the Grant Agency of the Czech Republic, through project P105/10/1574, and the Academy of Sciences of the Czech Republic, through Institutional Research Plan AV0Z20600510.

\section{List of symbols}

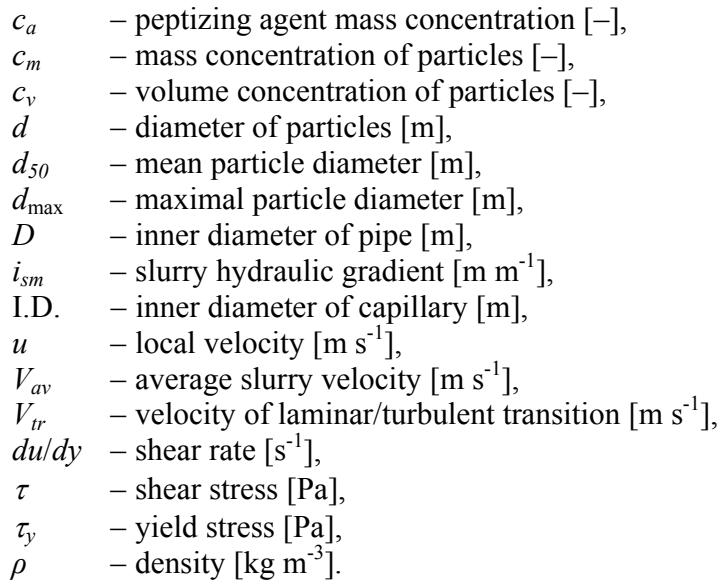

\section{REFERENCES}

HORSLEY R.R., SNOW R.J., 1988: The rheology of some Australian mine tailings. Proc. Progress and Trends in Rheology II, Prague (Czechoslovakia), 17-20 June 1986, Ed. H. Giesekus, M.F. Hibberd, Steinkopff, Darmstadt, 1988, pp. 344-346.

KEENTOK M., 1982: The measurement of the yield stress of liquids. Rheol. Acta, 21, pp. 325-332.

NGUYEN Q.D., BOGER D.V., 1984: Exploiting the rheology of highly concentrated suspensions. Proc. IX. Int. Congress on Rheology, Acapulco, Mexico, 8-13 October 1984, Ed. B. Mena, pp. 153-171.

SCHOFFIELD R.K., SAMSON H.R., 1954: Flocculation of kaolinite due to the attraction of oppositely charged crystal faces. Discussions Faraday Soc., 18, (Coagulation and Flocculation), pp. 135-145.

ŠATAVA V., 1973: Teorie ztekucování keramických licích břeček a optimalizace procesu lití. (In Czech.) Sklář a keramik, XXIII, pp. 195-199.

VERWEY E.J.W., OVERBECK J.TH.G., 1948: Theory of the Stability of Lyophobic Colloids. Elsevier, Amsterdam 1948. 
VLASAK P., CHARA Z., 1999: Laminar and turbulent flow experiments with yield-power law slurries. Powder Technology, 104, pp. 200-206.

VLASAK P., CHARA Z., 2004: Laminar and turbulent transition of fine-grained slurries. Particulate Science and Technology, 22, 2, pp. 189-200.

VLASAK P., CHARA Z., 2009: Conveying of Solid Particles in Newtonian and Non-Newtonian Carriers. Particulate Science and Technology, 27, 5, pp. 428-443.

VLASAK P., CHARA Z., STERN P., 1999a: Liquefying of dense clay-water mixtures. Proc. Problems in Fluid Mechanics and Hydrology, IH ASCR, Prague (Czech Republic), 23-26 June 1999, pp. 190-198.

VLASAK P., CHARA Z., STERN P., 1999b: Effect of peptisation on flow behaviour of clay suspension. Proc. HYDROTRANSPORT 14, BHR Group Conf. Series No. 36, Maastricht (The Netherlands), 8-10 September 1999, pp. 347-358 .

VLASAK P., CHARA Z., STERN P., KONFRŠT J., ELNAHHAS K., 2002: Flow behaviour and drag reduction of kaolin suspensions. Proc. HYDROTRANSPORT 15, BHR Group Conf. Series, Banff (Canada), 3-5 June 2002, pp. $345-360$.

VYCUDILÍK P., 1974: Ztekucování a ztekucovadla v keramických suspenzích. (In Czech.) Sklář a keramik, XXIV, pp. 201-208.

Received 9 March 2010

Accepted 26 October 2010

\section{SNIŽOVÁNÍ TŘENÍ ZAHUŠŤĚNÝCH JEMNOZRNNÝCH SUSPENZÍ}

\section{Pavel Vlasák, Zdeněk Chára, Petr Štern}

Přitažlivé a odpudivé síly působící mezi částicemi $\mathrm{v}$ homogenní suspenzi $\mathrm{v}$ důsledku různých iontů absorbovaných povrchem jemných, zejména koloidních částic, silně ovlivňují tokové chování vysoce koncentrovaných jemnozrnných suspenzí. Pokud jsou přitažlivé síly mezi jemnými částicemi v dané suspenzi dominantní, iniciují proces koagulace, jsou prričinou vzniku velkoobjemových agregátů $v$ nichž je vázáno značné množství vody. Změna fyzikálně-chemického prostředí suspenze přidáním peptizačního činidla podnítí vznik odpudivých sil mezi částicemi, které způsobí rozrušení velkoobjemových agregátů a voda vázaná $\mathrm{v}$ agregátech se uvolní, vazké tření tak může hrát $\mathrm{v}$ suspenzi významnější roli a dojde $\mathrm{k}$ ztekucení suspenze.

Tento proces byl ověren experimentálním výzkumem třech různých kaolinových suspenzí jednak na kapilárním přetlakovém viskozimetru, na rotačním viskozimetru a také $\mathrm{v}$ experimentální potrubní trase. Byl ověřen účinek dvou peptizačních činidel, uhličitanu sodného, který zásobuje suspenzi jednomocnými kationty sodíku, které kompensují povrchový náboj částic, a sodného vodního skla, které representuje peptizační činidla s koloidálním aniontem.

Tokové chování kaolinových suspenzí je řízeno vzájemným účinkem přitažlivých a odpudivých sil mezi pevnými částicemi, které jsou určeny fyzikálními a che- mickými vlastnostmi nosné i nesené fáze. Peptizační činidlo významně ovlivňuje tokové chování kaolinových suspenzí a pomáhá dosáhnout mnohem vyšších koncentrací a snižuje energetické nároky při proudění kaolinových suspenzí v potrubí. S rostoucí koncentrací peptizačního činidla zdánlivá viskozita a počáteční napětí suspenze postupně klesají, počáteční napětí téměř mizí. Pro vyšší koncentrace peptizačního činidla byla dokonce pozorována tendence přechodu nenewtonovského chování $\mathrm{k}$ newtonovskému.

Účinnost procesu ztekucování závisí na koncentraci peptizačního činidla, na koncentraci pevné fáze a na rychlosti proudění suspenze. Účinek peptizačního činidla vzrůstá s rostoucí koncentrací pevné fáze a projevuje se významně zejména pro laminární režim proudění. Pro přechodný režim proudění vliv peptizačního činidla výrazně klesá a pro turbulentní režim proudění obvykle zcela vymizí. Pozitivní účinek na energetickou spotřebu je proto nutno vyhodnotit pro každý jednotlivý př́pad zvláśs'. Pro peptizované suspenze je dosahováno přechodu z laminárního do turbulentního režimu proudění při významně nižších hodnotách rychlosti proudění než pro nestabilizované suspenze.

Uskutečněný výzkum potvrdil, že již velmi nízká koncentrace peptizačního činidla vede k podstatnému snižení vnitřního tření $\mathrm{v}$ suspenzi, $\mathrm{k}$ významné redukci zdánlivé viskozity a počátečního napětí vysoce koncentrovaných jemnozrnných suspenzí obsahujících koloidní částice pomocí úpravy jejich fyzikálně-chemického chování. Přidáním peptizačního činidla je možné dosáhnout mnohem vyšších provozních koncentrací pevné fáze a/nebo velmi výhodného snížení energetických nároků pro potrubní dopravu, manipulaci nebo zpracování průmyslových suspenzí.

Ř́zení a úprava fyzikálně chemického chování suspenze a její vniťrní struktury umožňuje optimalizovat jak spotřebu energie, tak i potřebu vody, zlepšit kvalitu a ekonomiku dopravních a manipulačních procesů a technologie zpracování suspenzí a dopravovaných materiálů.

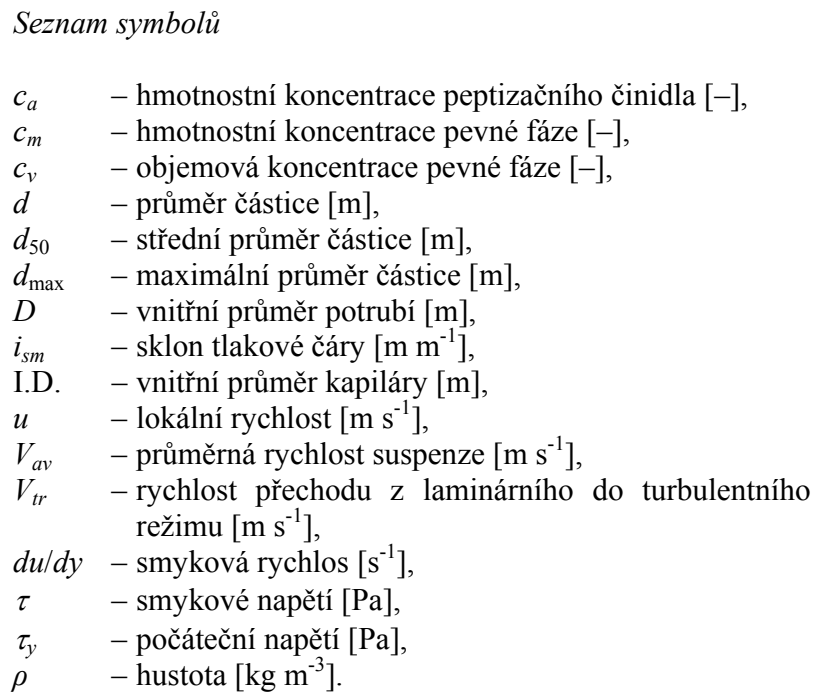

